\title{
Savings and Financial Literacy: A Review of Selected Literature*
}

\author{
ANA BROCHADO ${ }^{\mathrm{a}}$ and VICTOR MENDES ${ }^{\mathrm{b}}$ \\ a ISCTE - Instituto Universitário de Lisboa and DINÂMIA'CET - ISCTE, Portugal; ' CMVM \\ - Comissão do Mercado de Valores Mobiliários and CICEE - Centro de Investigação em Ciências \\ Económicas e Empresariais
}

To cite this article: Brochado, A. \& V. Mendes. 2021. Savings and Financial Literacy: A Review of Selected Literature. European Review of Business Economics I(1): 61-72; DOI: https://doi.org/10.26619/ERBE2021.01.3.

\begin{abstract}
This paper presents a systematic review of the literature on financial literacy and savings. A total of 183 articles published between 2005 and 2019 were analyzed. The review relied on hybrid methods, namely, descriptive, semantic network and narrative analyses. The lexical analysis of the articles' abstracts identified 11 themes: financial literacy, financial literacy measurement, correlates, savings, savings type, financial education, target group, theories, personal finance, financial preparation and financial inclusion. The findings include avenues for future research.
\end{abstract}

SAVING CAN BE VIEWED AS POSITIVE FINANCIAL BEHAVIOR (Organization for Economic Co-operation and Development [OECD], 2016) that translates into financial wellbeing for individuals and households. Long-term savings offer opportunities to engage in regular consumption throughout people's life cycle, and short-term or emergency savings provide purchasing power protection in the event of income shocks (Mahdzan and Tabiani 2013). Various studies have analyzed the factors that influence individuals' saving behavior and highlighted the role of financial literacy (e.g., Cupák, Kolev and Brokešová 2019; Pak and Chatterjee 2016; Ramalho and Forte 2019), which has an important function in financial decision-making, especially given the increasing complexity of financial systems (Potrich, Vieira and Mendes-Da-Silva 2016). People must acquire not only financial knowledge but also the ability and confidence to apply this expertise when making financial decisions (Huston 2010). Increasing financial literacy is part of the agendas of both governments and international organizations (OECD 2016), and this topic has received increasing attention within the academic community (Pak and Chatterjee 2016).

* The opinions expressed in this article are those of the authors, and do not necessarily reflect the official position of the CMVM. The Portuguese version of this paper has been accepted for publication in Cadernos do Mercado de Valores Mobiliários (forthcoming). 
This paper presents a systematic review of the literature on financial literacy and savings. More specifically, the following research questions are addressed:

1. What are academics' main contributions to the study of financial literacy and savings?

2. What are the main methodological approaches used in research on financial literacy and savings?

3. What are the main themes analyzed within the field of financial literacy and savings?

4. What avenues for future research remain to be explored?

\section{Methodology}

This systematic literature review analyzed published papers identified by a search for the terms 'financial literacy' and 'saving' in keywords, titles and abstracts listed in the Scopus database. The selected articles are available in English in journals covering the areas of 'business, management and accounting' or 'economics, econometrics and finance'. A total of 183 articles published between 2005 and 2019 were found by using the following query: TITLE-ABS-KEY ('savings' AND 'financial literacy') AND (LIMIT-TO (DOCTYPE, 'ar') OR LIMIT-TO (DOCTYPE, 're')) AND (LIMIT-TO (LANGUAGE, 'English')) AND (LIMIT-TO (SRCTYPE, 'j') AND (LIMIT-TO (SUBJAREA, 'ECON') OR LIMIT-TO (SUBJAREA, 'BUSI')).

A spreadsheet was created with the following information on each paper: article title, year, abstract, keywords, authors, authors' affiliation, and journal. The approach adopted was a systematic review based on hybrid methods that combined descriptive, semantic network and narrative analyses. The descriptive analysis revealed the evolution of the studies through journals, authors, keywords, geographic scope and main methods. Next, a content analysis of the articles was performed using Leximancer, a software application that automatically extracts semantic networks from qualitative data. This software has been used in previous systematic literature reviews (e.g., Crofts and Bisman 2010; Lima et al., 2021) to generate concept maps based on the co-occurrence of words present in abstracts. The present semantic analysis identified the main themes in the abstracts and explored the relationships between key themes. The narrative analysis produced a description of the main themes included in the Leximancer concept map. 


\section{Results}

\section{A. Descriptive Analysis}

Research on the relationship between financial literacy and savings is a relatively recent topic in academic literature. Half of the 183 articles under analysis were published between 2016 and 2019, and approximately 20 percent of the papers were published in 2019, appearing overall in 109 different journals. Eight journals account for 28 percent of the studies: Journal of Pension Economics and Finance, Journal of Consumer Affairs, International Journal of Bank Marke- ting, International Journal of Consumer Studies, Journal of Family and Eco- nomic Issues, Journal of Financial Counseling and Planning, Economics and Sociology and Journal of Banking and Finance. The database consulted regis- ters 425 different authors, of whom 393 authors (co)authored only one article. The two most productive scholars in this field are A. Lusardi of George Washin-gton University School of Business, in Washington, DC, and O.S. Mitchell of University of Pennsylvania's Wharton School, in Philadelphia, PA - both located in the United States (US).

Only 10 articles discuss conceptual and/or theoretical studies. The majority of the 173 empirical research papers targeted only one country (161 studies), and only 12 adopted a cross-country approach. The articles cover a wide geographical area including 63 different countries. The countries focused on by the largest number of studies are the US (43 studies), India (17), Australia (15), Germany (13), Malaysia (13), the Netherlands (12), the United Kingdom (9), Israel and Italy (6) and France, Ghana, Slovakia and Sweden (5).

The empirical research, using regression analysis to examine the savings' link with financial literacy, adopted a variety of econometric methods. These included, among others, structural equation modeling (Potrich, Vieira and Mendes-Da-Silva 2016), partial least squares path modeling (Zulaihati, Susantiand Widyastuti 2020), regression analysis (Lusardi and Mitchell 2011; Sekita 2011), instrumental regression (Bucher-Koenen and Lusardi 2011; van Rooij, Lusardi and Alessie 2012), logistic regression/logit regression (Heckman and Hanna 2015; Pak and Chattwejww 2016, de Cecco and Estache 2016; Nguyenet al. 2017), probit models (Babiarz and Robb 2014; Mahdzan and Tabiani 2013; Murendo and Mutsonziwa 2017) and ordinal regression (Brounen, Koedijk and Pownall 2016; Loke 2016). The cited studies gathered primary data by developing questionnaires (e.g., Murendo and Mutsonziwa 2017; Potrich, Vieira and Mendes-Da-Silva 2016) and secondary microdata with instruments such as the OECD's financial literacy questionnaire (Loke 2016; Ramalho and Forte 2019), the National Financial Capability Study in the US (Henager-Greene and Cude 2016; Pak and Chatterjee 2016) and the Survey of Living Preferences and Satisfaction (Bucher-Koenen and Lusardi 2011; Sekita 2011). 


\section{B. Semantic Analysis}

A content analysis of the abstracts of 183 articles using Leximancer identified 14 themes, which were further reduced into 11 themes (see Figure 1) as outlined below:

1. The financial literacy theme includes the concepts of financial (knowledge), literacy, significant (topic), level, self-efficacy and training.

2. The theme of financial literacy measurement contains the perceived (knowledge), actual (expertise), survey, development, attitude, data, self-control, behavior, self-confidence and knowledge concepts.

\section{Figure 1 \\ Conceptual Map (Number $=183$ Abstracts $)$}

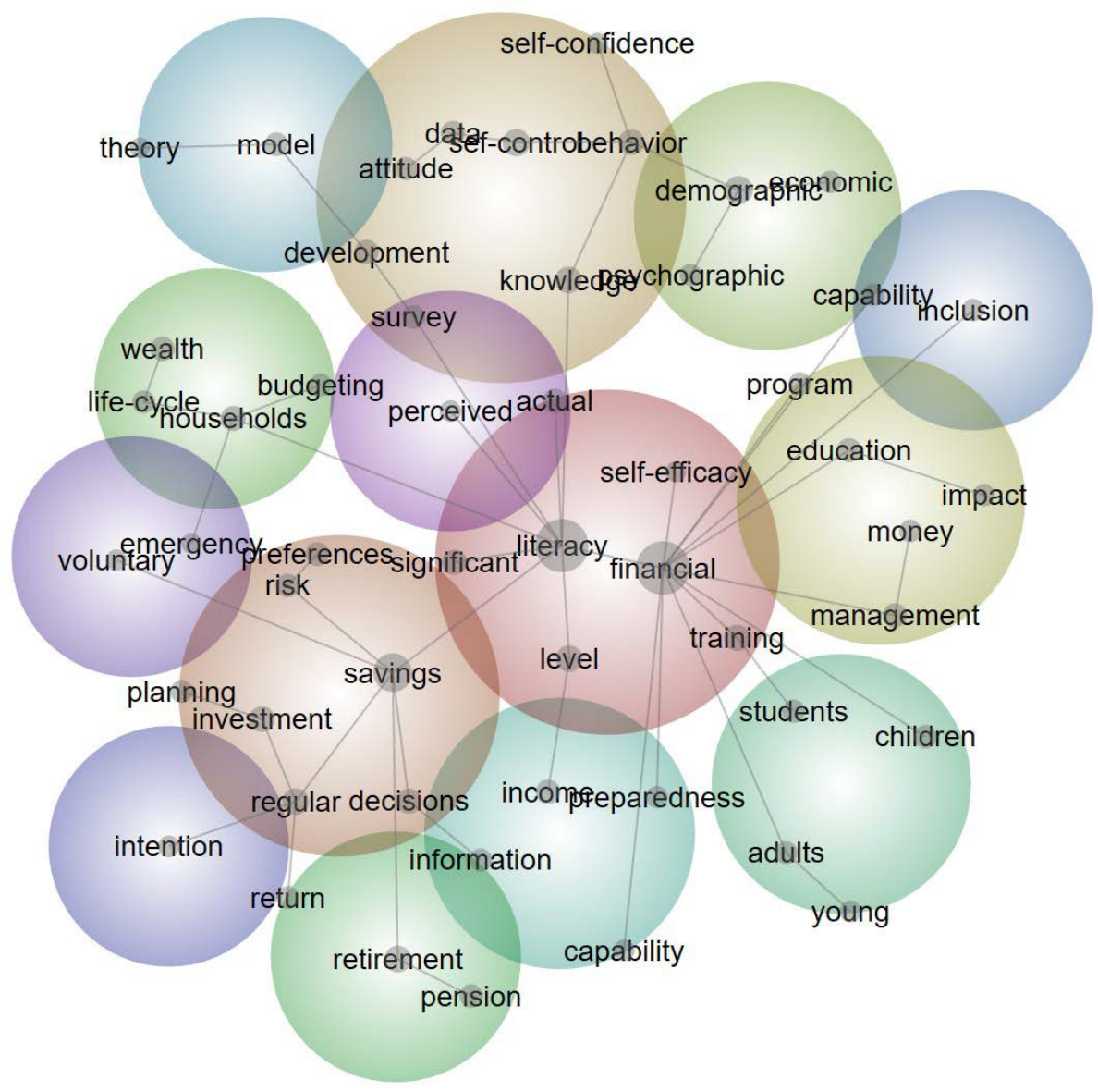


3. The 'correlates' theme encompasses the concepts of demographic(s), economic (factors) and psychographic(s).

4. The 'savings' theme includes the concepts of savings, risk, preferences, decisions, regular (deduction), investment and planning.

5. The theme of savings type contains the emergency, voluntary (deduction), intention, return, retirement and pension concepts.

6. The theme of financial education includes the concepts of education, programme, impact, money and management.

7. The target group theme comprises the concepts of students, children, adults and young (individuals).

8. The 'theories' theme covers the theory and model concepts.

9. The theme of personal finance includes the concepts of the household, budgeting, life cycle and wealth concepts.

10. The preparedness theme includes the concepts of preparedness, capability, income and information.

11. The inclusion theme comprises the inclusion and capability concepts.

\section{Narrative Analysis}

\section{C.1. Financial Literacy}

According to Huston (2010), the definition of financial literacy has evolved from merely being knowledgeable about financial matters (i.e., understanding) to additionally integrating the ability to apply knowledge to daily financial decisions (i.e., use). Huston $(2010,306)$ defines financial literacy, more specifically, as 'measuring how well an individual can understand and use personal finance-related information'. This concept is related to individuals' ability to obtain, understand, and evaluate the information needed to make practical personal finance decisions (Xue et al. 2019). The OECD (2016) states that financial literacy is people's capacity to use the knowledge and skills they acquire. This conceptual model thus involves three dimensions: financial knowledge, attitudes, and behavior (OECD/International Network on Financial Education [INFE] 2011).

Empirical research has found that financial literacy is associated with shortand long-term financial behavior. Individuals with high levels of financial literacy are more likely to make good choices regarding savings and low indebtedness levels. For example, this kind of literacy is positively related to retirement planning (Bongini and Cucinelli 2019), savings over the previous 12 months (Mahdzan and Tabiani 2013) and financial preparation for income shocks (Loke 2016).

\section{C.2. Measuring Financial Literacy}

The literature reveals a lack of consensus on how to operationalize and measure financial literacy (Ramalho and Forte 2019; Xue et al. 2019). Many studies assessed financial literacy based on observed financial knowledge. This one-dimensional 
view highlights the importance of a correct understanding of financial concepts (Boisclair, Lusardi and Michaud 2017; Cupák, Kolev and Brokešová 2019; Jappelli and Padula 2015; Lusardi and Mitchell 2011; Van Rooij, Lusardi and Alessie 2012). Observed financial knowledge can be subdivided into basic knowledge about topics such as compound interest, inflation, time value of money and monetary illusion and advanced knowledge about topics such as asset risk, long-term return, volatility, and diversification (Nguyen et al. 2017; Potrich, Vieira and Mendes-Da-Silva 2016). Other research (Zulaihati, Susanti and Widyastuti 2020) measured perceived knowledge through self-confidence. A third group of studies simultaneously considered current knowledge and perceived knowledge as indicators of financial literacy and determinants of saving behavior (Babiarz and Robb 2014).

In addition, the literature discusses the relationship between current and perceived knowledge, with an emphasis on two scenarios. First, limited observed knowledge and extensive perceived expertise contribute to overconfidence. Second, broad observed knowledge and restricted perceived expertise result in underconfidence (Ramalho and Forte 2019), so under- and overconfidence are behavioral biases that can influence financial behavior. Pak and Chatterjee (2016) focused on both observed and perceived knowledge and measured financial literacy's impact on savings (i.e., emergency and retirement) for the study's entire sample and overconfidence group.

The literature has also discussed financial literacy's multidimensional role and analyzed the relationships between the three dimensions mentioned previously (see section C.1). For instance, the model proposed by Potrich, Vieira and Mendes-Da-Silva (2016) and Ramalho and Forte (2019) incorporates current financial knowledge, perceived financial knowledge and financial attitude as antecedents of financial behavior. Potrich, Vieira and Mendes-Da-Silva (2016) compared three models with different relationships between the components of financial literacy, behavior, knowledge, and attitude and concluded that financial knowledge and attitude are correlated with and mutually predict financial behavior. Murendo and Mutsonziwa (2017) applied a multivariate approach to measuring financial literacy, including financial attitude, confidence, and knowledge.

\section{C.3. Demographic, Psychographic and Socioeconomic Correlates}

Different econometric models developed regarding the relationship between financial literacy and savings include a diverse set of explanatory and/or control variables. These include, among others, demographic and socioeconomic variables such as gender, age, household size, qualifications, marital status, income and/or wealth and employment status (Bongini and Cucinelli 2019; Cupák, Kolev and Brokešová 2019; Heckman and Hanna 2015; Lachance 2014). Other variables incorporated in models are risk tolerance (Brounen, Koedijk and Pownall 2016; Nguyen et al. 2017), attitudes, subjective norms, perceived control (Bongini and Cucinelli 2019), self-confidence, underconfidence (Ramalho and Forte 2019), institutional factors (Heckman and Hanna 2015) and cognitive, connotative, and affective factors (Kerry 2018). 


\section{C.4. Savings}

Saving is recognized as positive financial behavior that leads to families' improved wellbeing in the short and long term (Babiarz and Robb 2014; OECD 2016). Savings facilitate balanced consumption throughout individuals' life cycle and maintain purchasing power regardless of income shocks due to unemployment, disability, unanticipated medical expenses or the costs entailed by purchasing a home or car (Heckman and Hanna 2015).

\section{C.5. Savings Type}

Researchers have considered different time horizons when focusing on savings. Boisclair, Lusardi and Michaud (2017); Cupák, Kolev and Brokešová (2019); and de Cecco and Estache (2016) studied retirement savings, and Bongini and Cucinelli (2019) analyzed students' plans to save toward retirement. Other research has examined emergency savings (Babiarz and Robb 2014; Henager-Greene and Cude 2016; Loke 2016; 2017a; 2017b), which are usually defined as savings that can cover individuals' typical expenses for three months (Babiarz and Robb 2014). Nguyen et al. (2017), in turn, focused on regular saving habits, while Murendo and Mutsonziwa (2017) included savings over the previous 12 months when measuring people's savings. Brounen, Koedijk and Pownall (2016) identified individuals who save as those willing to sacrifice their present wellbeing to ensure specific results in the future. Henager-Greene and Cude (2016) and Pak and Chatterjee (2016) examined both long-term (i.e., retirement) and short-term savings (i.e., emergency). Finally, Murendo and Mutsonziwa (2017) applied the concept of 'savings portfolio', which includes formal (i.e., savings in financial institutions) and informal savings (i.e., non-institutional mechanisms).

\section{C.6. Financial Education}

Governments have sought to design more efficient approaches to increasing financial literacy through financial education (Potrich, Vieira and Mendes-Da-Silva 2016). This education is a process in which individuals develop a deeper understanding of financial products, key concepts, primary risks and skills that facilitate decisions about ways to manage personal finances successfully. Financial education contributes to financial literacy (Yong, Yew and Wee 2018), namely, how the relevant knowledge and skills can be applied (Potrich, Vieira and Mendes-Da-Silva 2016). Clark et al. (2014) concluded that training employees in retirement planning increases their intention to continue saving toward retirement plans. Financial education programs have been developed for different target groups and educational levels (Potrich, Vieira and Mendes-Da-Silva 2016).

\section{C.7. Target Groups}

Most of the empirical research on financial literacy and savings has relied on representative adult samples (Cupák, Kolev and Brokešová 2019; Ramalho and Forte 2019). Other studies have analyzed students (Bongini and Cucinelli 2019; de Cecco and Estache 2016; Potrich, Vieira and Mendes-Da-Silva 2016), millennials (Yong, Yew and Wee 2018), groups with higher-than-average financial 
literacy such as teachers (Zulaihati, Susanti and Widyastuti 2020) and US Federal Reserve System collaborators (Clark et al. 2014).

\section{C.8. Theories}

Various empirical research projects have been inspired by the life-cycle model of consumption and savings (Modigliani and Brumberg 1954) and consumption function (Friedman 1957). Based on the life-cycle theory, Fernández-López et al. (2010) suggest that the amount of savings increases with age. The financial literacy process was also analyzed from a behavioral perspective (Bongini and Cucinelli 2019; Yong, Yew and Wee 2018). In addition, the theory of planned behavior (TPB) (Ajzen 1991; 2002) assumes, in this context, that behavioral intentions are influenced by three variables. These are subjective norms (i.e., social pres- sure to engage in behavior), attitudes (i.e., subjective evaluations of favorable or unfavorable behavior) and perceived behavioral control (i.e., perceptions of individuals' ability to engage in behavior). Croy, Gerrans and Speelman (2010) further examined intent to save for retirement using a modified version of the TPB model, which includes the original base variables, as well as the importance of planning, preparation for planning and risk tolerance.

Beverly et al. (2008) developed a model tested most recently by Heckman and Hanna (2015), which assumes that saving behavior is influenced by two types of variables - individual and institutional. The former variables are economic resources and needs (i.e., income and expenses), social networks (i.e., peer-related incentives to save or not), financial literacy (i.e., knowledge of financial concepts and products) and psychological variables. Institutional factors are based on institutional theory, which assumes that 'individuals and households' saving behavio[u]r is shaped by the institutional processes through which saving occurs' (Beverly and Sherraden 1999, 463). Related studies have identified seven institutional factor dimensions: access, security, incentives, information, facilitation, expectations and limits (Heckman and Hanna 2015).

\section{C.9. Personal Finances}

Regarding personal finances, the OECD (2019) suggests that researchers need to analyze the following financial behavior: budgeting, savings, purcha- ses, payments, choice and selection of financial products, objectives and control. Saving is considered a positive behavior because it offers families a more stable consumption pattern throughout members' life cycle. Savings thus allow families to maintain their quality of life during periods of economic crisis or to deal with income shocks associated with unemployment, disability or retirement (Heckman and Hanna 2015).

\section{C.10. Financial Preparedness}

Loke (2016) examined families' financial preparedness for shocks. Various unplanned events (i.e., illness, disability, unemployment, and loss of income) can require families to reorganize their finances. Some events that trigger shocks may not be covered by insurance or social security systems. If families do not 
have the resources and liquidity to cope with shocks, they can incur excessive debt, so financial preparation is related to emergency funds. The literature reports that families are prepared for income shocks if they have resources that cover three months or more of normal expenses - without a loss of quality of life.If families can only cover 1 to 3 months (i.e., less than 1 month), their preparedness is considered to be moderate or weak (Loke 2016).

\section{C.11. Financial Inclusion}

Financial inclusion has been measured in terms of not only access to and use and quality of banking services but also the existence of bank accounts, savings, and bank loans (Lyons and Kass-Hanna 2019). The OECD (2016) defines financial inclusion as the continued promotion of all population segments' access to a wide variety of financial products and services through innovative approaches, including financial education. Financial literacy has, therefore, been positively associated with financial inclusion (Verma and Kumari 2016).

\section{Conclusion}

This study aimed to answer four research questions by conducting a systematic review of the literature on savings and financial literacy published until the end of 2019. Regarding the first question (i.e., What are academics' main contributions to the study of financial literacy and savings?), 183 papers were published in 109 different Scopus-indexed journals by 425 different authors. With respect to the second question (i.e., What are the main methodological approaches used in research on financial literacy and savings?), approximately 93 percent of the above studies relied on empirical research. While studies focused on 63 countries, the most frequently chosen countries were the US, India, Australia, Germany, Malaysia and the Netherlands. Empirical research that related different saving behavior to levels of financial literacy applied different methodologies in terms of data sources (i.e., primary vs secondary), type of savings studied and measured, approach to measuring financial literacy, control variables and econometric methods.

Concerning the third research question (i.e., What are the main themes analyzed within the field of financial literacy and savings?), lexical analysis of the articles' abstracts identified 11 different themes: financial literacy, measuring financial literacy, correlates, savings, savings type, financial education, target group, theories, personal finance, financial preparation and financial inclusion. The last research question focused on the potential for future research (i.e., what avenues of research remain to be explored?). In terms of methodology, 9 out of 10 empirical studies were carried out within a single country. Future research could capitalize on the OECD's common methodology developed for studies with cross-country designs.

In addition, researchers need to identify the channels by which financial literacy is translated into savings. Endogeneity in financial literacy as reflected by 
econometric models should also continue to be addressed. The variables used in self-assessments of savings can further be complemented with a conceptual framework that incorporates individuals' specific circumstances and needs.

Future research should also focus on biases (i.e., underconfidence vs overconfidence) - especially whether these affect the relationship between financial literacy and savings. Studies based on TPB using explanatory psychographic variables could further reveal the relative importance of variables such as attitudes, subjective norms and perceived controls. Financial education also needs to be examined more broadly to cover both psychographic areas and financial knowledge. Various researchers have found a positive connection between financial literacy and savings, and many governments are committed to developing financial literacy programs. Future work should thus assess specific programs designed to meet the financial literacy needs of different market segments.

\section{REFERENCES}

DeAngelo, H., A. Goncalves \& R. Stulz. 2018. Corporate Deleveraging and Financial Flexibility. Review of Financial Studies 31(8): 3122-3174.

Ajzen, I. 1991. The Theory of Planned Behavior. Organizational Behavior and Human Decision Processes 50: 179-211.

Ajzen, I. 2002. Perceived Behavioral Control, Self-efficacy, Locus of Control, and the Theory of Planned Behavior. Journal of Applied Social Psychology 32(4): 665-683.

Babiarz, P. \& C.A. Robb. 2014. Financial Literacy and Emergency Saving. Journal of Family and Economic Issues 35: 40-50.

Beverly, S. G. \& M. Sherraden. 1999. Institutional Determinants of Saving: Implications for Lowincome Households and Public Policy. Journal of Socioeconomics 28(4): 457-473.

Beverly, S., M. Sherraden, R. Cramer, T. Shanks, Y. Nam \& M. Zhan. 2008. Determinants of asset holdings. In S.-M. McKernan \& M. Sherraden (Eds.), Asset building and low-income families (pp. 89-151). Washington, DC: The Urban Institute Press.

Boisclair, D., A. Lusardi \& P. Michaud. 2017. Financial Literacy and Retirement Planning in Canada. Journal of Pension Economics and Finance 16(3): 277-296.

Bongini, P. \& D. Cucinelli. 2019. University Students and Retirement Planning: Never Too Early. International Journal of Bank Marketing 37(3): 775-797.

Brounen, D., K. Koedijk \& R. Pownall. 2016. Household Financial Planning and Savings Behavior. Journal of International Money and Finance 69: 95-107.

Bucher-Koenen, T. \& A. Lusardi. 2011. Financial Literacy and Retirement Planning in Germany. Journal of Pension Economics and Finance 10(4): 565-584.

Clark, R., J. Maki \& M. Morrill. 2014. Can Simple Informational Nudges Increase Employee Participation in a 401(k) Plan? Southern Economic Journal 80(3): 677-701.

Crofts, K. \& J. Bisman. 2010. Interrogating Accountability: An Illustration of the Use of Leximancer Software for Qualitative Data Analysis. Qualitative Research in Accounting and Management 7(2): 180-207.

Croy, G., P. Gerrans \& C. Speelman. 2010. The Role and Relevance of Domain Knowledge, Perceptions of Planning Importance, and Risk Tolerance in Predicting Savings Intentions. Journal of Economic Psychology 31: 860-871.

Cupák, A., G. Kolev \& Z. Brokešová. 2019. Financial Literacy and Voluntary Savings for Retirement: Novel Causal Evidence. The European Journal of Finance 25(16): 1606-1625.

de Cecco, S. \& A. Estache. 2016. Is the Belgian Youth Ready to Save for Retirement Under a Defined Contribution Pension System? Reflets et Perspectives de la Vie Économique IV(3): 99-118.

Fernández-López, S., L. González, R.-P. David \& M. Búa. 2010. What Are the Driving Forces of Individuals' Retirement Savings? Czech. Journal of Economics and Finance (Finance a Uver) 60(3): 226-251. 
Friedman, M. 1957. A Theory of the Consumption Function National Bureau of Economic Research. https://EconPapers.repec.org/RePEc:nbr:nberbk:frie57-1

Heckman, S. \& S. Hanna. 2015. Individual and Institutional Factors Related to Low-Income Household Saving Behavior. Journal of Financial Counseling and Planning 26: 197-199.

Henager-Greene R. \& B.J. Cude. 2016. Financial Literacy and Long- and Short-Term Financial Behavior in Different Age Groups. Journal of Financial Counseling and Planning 27(1): 3-19.

Huston, S.J. 2010. Measuring Financial Literacy. Journal of Consumer Affairs 44(2): 296-316.

Jappelli, T. \& M. Padula 2015. Investment in Financial Literacy, Social Security, and Portfolio Choice. Journal of Pension Economics and Finance 14(4): 369-411.

Kerry, M.J. 2018. Psychological Antecedents of Retirement Planning: A Systematic Review Frontiers in Psychology 9,1870.

Lachance, M.-E. 2014. Financial Literacy and Neighborhood Effects. Journal of Consumer Affairs 48(2): 251-273.

Lima, S., A. Brochado \& R. Marques. 2021. Public-private partnerships in the water sector: A review. Utilities Policy.

Lyons, A.C. \& J. Kass-Hanna. 2019. Financial Inclusion, Financial Literacy and Economically Vulnerable Populations in the Middle East and North Africa Emerging Markets Finance and Trade 22 April.

Loke, Y. 2016. Financial Preparedness for Income Shock among Malaysians. Malaysian Journal of Economic Studies 53(2): 279-295.

Loke, Y. 2017a. Financial Vulnerability of Working Adults in Malaysia Contemporary Economics 11(2): 205-218

Loke, Y. 2017b. The Influence of Socio-demographic and Financial Knowledge Factors on Financial Management Practices of Malaysians. International Journal of Business and Society 18: 33-50.

Lusardi, A. \& O. Mitchel. 2011. Financial Literacy and Retirement Planning in the United States. Journal of Pension Economics and Finance 10(4): 509-525.

Mahdzan, N. \& S. Tabiani. 2013. The Impact of Financial Literacy on Individual Saving: An Exploratory. Study in the Malaysian Context. Transformations in Business and Economics 12(1): 41-55.

Modigliani, F. \& R.H. Brumberg. 1954. Utility Analysis and the Consumption Function: An Interpretation of Cross-Section Data in Post-Keynesian Economics by K.K. Kurihara, Ed., Rutgers University Press: New Brunswick: 388-436.

Murendo, C. \& K. Mutsonziwa. 2017. Financial Literacy and Savings Decisions by Adult Financial Consumers in Zimbabwe. International Journal of Consumer Studies 41(1): 95-103.

Nguyen, T., Z. Rózsa, J. Belás \& L. Belásová. 2017. The Effects of Perceived and Actual Financial Knowledge on Regular Personal Savings: Case of Vietnam. Journal of International Studies 10(2): 278-91.

Organization for Economic Co-operation and Development. 2016. OECD/INFE International Survey of Adult Financial Literacy Competencies www.oecd.org/finance/OECD-INFE-InternationalSurvey-of-Adult-Financial-Literacy-Competencies.pdf

Organization for Economic Co-operation and Development. 2019. OECD/INFE Survey Instrument to Measure the Financial Literacy of MSMEs https://www.oecd.org/financial/education/2019survey-to-measure-msme-financial-literacy.pdf

Organization for Economic Co-operation and Development/International Network on Financial Education. 2011. Measuring Financial Literacy: Core Questionnaire in Measuring Financial Literacy: Questionnaire and Guidance Notes for conducting an Internationally Comparable Survey of Financial Literacy https://www.oecd.org/finance/financial-education/49319977.pdf

Pak, T.-Y. and S. Chatterjee. 2016. Savings Decisions of American Households: The Roles of Financial Literacy and Financial Practice. Economics Bulletin 36(3): 1486-1496.

Potrich, A.C.G., K.M. Vieira \& W. Mendes-Da-Silva. 2016. Development of a Financial Literacy Model for University Students. Management Research Review 39(3): 356-376.

Ramalho, T.B. \& D. Forte. 2019. Financial Literacy in Brazil - Do Knowledge and Self-confidence Relate With Behavior? RAUSP Management Journal 54(1): 77-95.

Sekita, S. 2011. Financial Literacy and Retirement Planning in Japan. Journal of Pension Economics and Finance 10(4): 637-656. 
van Rooij, M., A. Lusardi \& R. Alessie. 2012. Financial Literacy, Retirement Planning and Household Wealth. Economic Journal, Royal Economic Society 122(560): 449-478.

Verma, S. \& O. Kumari. 2016. Role of Financial Literacy in Achieving Financial InclusionInternational. Journal of Applied Business and Economic Research 14(6): 4607-4613.

Xue, R., A. Gepp, T.J. O’Neill, S. Stern \& B.J. Vanstone. 2019. Financial Literacy Amongst ElderlyAustralians. Accounting \& Finance 59: 887-918.

Yong, C.-C., S.-Y. Yew \& C.-K. Wee. 2018. Financial Knowledge, Attitude and Behaviour of YoungWorking Adults in Malaysia. Institutions and Economies 10(4): 21-48.

Zulaihati, S., S. Susanti \& U. Widyastuti. 2020. Teachers' Financial Literacy: Does it Impact on Financial Behaviour? Management Science Letters 10(3): 653-658. 